\title{
New species of the subgenus Choilisanus REITTER, 1912 of the genus Otiorhynchus GERMAR, 1822 (Coleoptera: Curculionidae: Entiminae: Otiorhynchini) from Turkey and Bulgaria
}

\author{
PIOTR Z. BIAŁOOKI ${ }^{*}$ \\ State Plant Health and Seed Inspectorate, ul. Na Stoku 48, 80-874 Gdańsk, Poland

\begin{abstract}
The following species of the genus Otiorhynchus are described: $O$. podlussanyorum sp. n. from Bulgaria, O. brunneiformis sp. n. and O. mogulonoides sp. n. from Turkey (all from the subgenus Choilisanus).

KEY WORDS: Otiorhynchus, new species, taxonomy, Bulgaria, Turkey.
\end{abstract}

\section{INTRODUCTION}

Although several new species representing the subgenus Choilisanus REITTER, 1912 were published quite recently by the same author (BIAŁOOKI 2016), surprisingly, further species were subsequently discovered; their descriptions are presented here. The subgenus Choilisanus now belongs to one of the largest in the genus Otiorhynchus GERMAR, 1822: at present the total number of species is around 50, including the three described in the present paper. The exact number is still uncertain, as some species included in the subgenus should, apparently, be transferred to other placements. This issue will be dealt with in detail in a forthcoming revision.

\footnotetext{
*Corresponding author: pbialooki@poczta.onet.pl
} 


\section{MATERIAL AND METHODS}

The width of the rostrum is consistently defined as the pterygial span, i.e. the distance between the outer margins of the pterygia, even though the basal width of the rostrum in front of the eyes may sometimes be longer. Other basic terms, "frons" in particular, were defined in BIAŁOOKI (2015). Here, some additional comments. The homology of particular regions of the weevil head with rostrum remains unclear, although some weevil specialists have started to use morphological terms (mainly "frons" and "epifrons") when referring to the evolutionary origin of particular sclerites, following the hypothesis formulated by DUPORTE (1960). The enigmatic treatment of the problem in the recently published Handbook of Zoology (OBERPRIELER et al. 2014) is symptomatic of the situation: the overwhelming majority of weevil specialists simply ignore DuPorte's concept. The sutures between the two regions are completely obliterated and invisible in the vast majority of Curculionoidea: but also in Entiminae, in which the dorsal wall of the rostrum is relatively well differentiated, the two regions pose many problems. For example, some authors identify "frons" as the whole anterior part of the dorsal wall of the rostrum in front of the antennal insertions except for the epistome, but such an interpretation is obviously incorrect. Unless and until the hypothesis by DUPORTE (1960), intuitively correct, is worked out into a comprehensive theory applicable to all Curculionoidea, it seems reasonable to use traditional terms (e.g. "frons" as the area between the eyes).

"Eyes/pterygia projecting" means eyes/pterygia extending from the outline of the head/rostrum in the dorsal view respectively, regardless of their convexity. The length of the funicle segments, as well as the club, is measured without the basal condyle (except for the first segment). Multi-layered photos were taken with a Leica M205C stereomicroscope with an attached JVC KYF75 digital camera and subsequently montaged using the AutoMontage software of Syncroscopy. Labels are always cited verbatim, comments/additions in brackets []; "" separates the labels of a given specimen, whereas "I" separates data concerning different specimens; "ht" denotes holotype; "ex.", "exx." specimen and specimens respectively.

Body length is measured in accordance with standard practice in Curculionoidea, i.e. from the anterior margin of the eyes to the elytral apex.

Acronyms: BIAL - collection of Piotr Z. BIAŁOOKI, Sopot, Poland; MERE - collection of Massimo Meregalli, University of Torino, Italy; PODL - collection of Attila PoDLUSSÁNY, Budapest, Hungary; NHMW - Naturhistorisches Museum Wien, Austria. 


\section{RESULTS}

Subfamily Entiminae

Tribe Otiorhynchini

Genus Otiorhynchus GERMAR, 1822 (type species Otiorhynchus rhacusensis GERMAR, 1822)

Subgenus Choilisanus (type species Otiorhynchus balcanicus STIERLIN, 1861)

Otiorhynchus (Choilisanus) podlussanyorum sp. n.

(Figs. 1-3)

\section{Material examined}

Holotype male dissected: Bulgaria, Kresna, Struma-völgy [= valley], 2007. VI.25. leg. KotÁn Attila/ Otiorhynchus elegantinus Angelov, det. A. PodlussánY 2013/ Coll. PODLUSSÁNY A. [PODL].

\section{Diagnosis}

The new species (Fig. 1) seems most similar to Otiorhynchus grandicollis BOHEMAN, 1842, sharing the characteristically very large pterygia. However, it differs from that species in the much smaller body $(O$. grandicollis $7.5-9.1 \mathrm{~mm})$, the more robust antennae, the strikingly less developed pronotal tubercles, the shorter (in O. grandicollis $1.5 \times$ longer than broad) and clearly egg-shaped elytra (narrowly oval, weakly rounded at base in $O$. grandicollis). $O$. latinasus REITTER, 1898 is readily distinguishable from $O$. podlussanyorum by the punctate pronotal disc, by the even larger pterygia, the shorter rostrum (nearly $1.3 \times$ broader than long), and the shorter, apically broader rounded elytra.

\section{Description (male)}

Body length $5.9 \mathrm{~mm}$, entirely dark brown.

Head rather strongly tapering, together with basal part of rostrum creating common cone, covered with moderately large deep punctures, and with minute thin dark brown recumbent hairs; frons unclearly separated from rostrum; eyes $1.3 \times$ shorter than width of frons, slightly oval, hardly projecting; temples clearly shorter than half of longitudinal eye diameter.

Rostrum slightly broader than long; pterygia extremely large, $1.5 \times$ broader than minimum width of rostrum; epistome heavily hollowed, epistomal keels well-developed. 


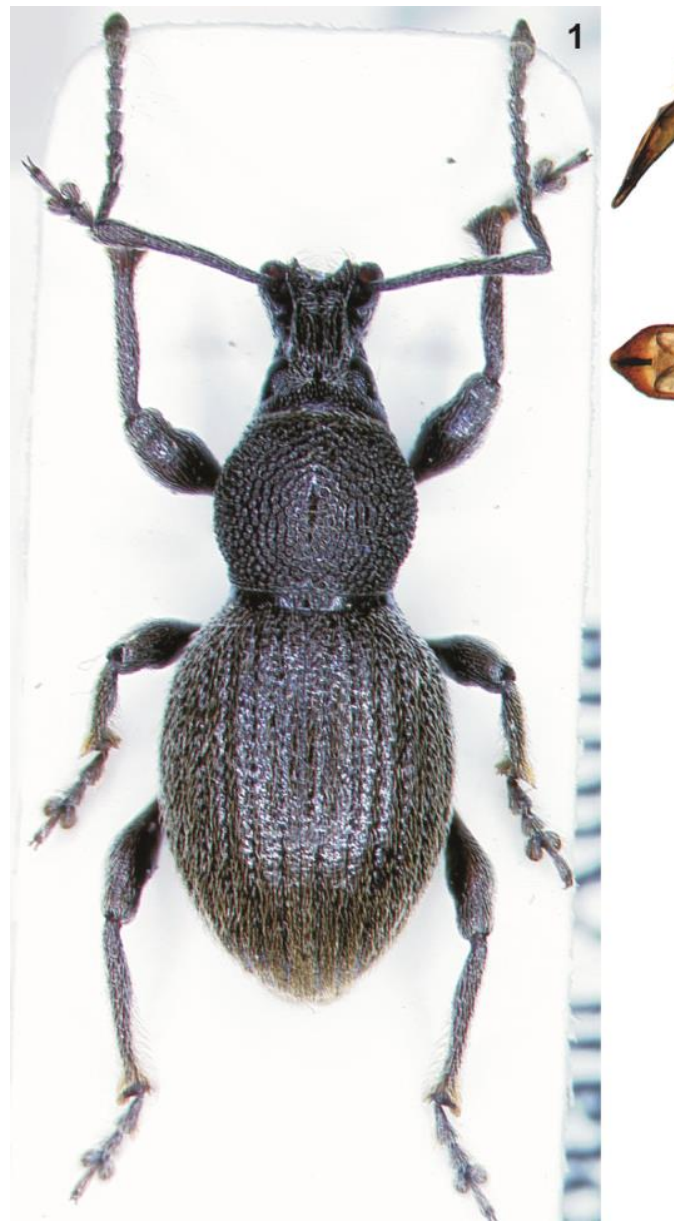

Figs. 1-3. Otiorhynchus podlussanyorum sp. n.: $\mathbf{1}$ - male habitus, $\mathbf{2}$ - aedagus dorsal, $\mathbf{3}$ - aedagus profile.

Antennae fairly slender; scape straight, indistinctly thickened apicad; all funicle segments elongate, gradually thickening apicad, subequally wide; first funicle segment very much longer than second; third segment $1.5 \times$ longer than wide; segments 4-7 somewhat less elongate; club elongate, fusiform.

Prothorax $1.2 \times$ broader than long, moderately convex, broadest in middle, sides moderately evenly convex, anterior margin somewhat narrower than base; disc predominantly covered with small, dense tubercles; vestiture consisting of subrecumbent light brown hair-like scales. Elytra slightly ovate, $1.4 \times$ longer than wide; longitudinally evenly moderately convex, apical declivity rather weakly convex; striae narrow, slightly impressed, punctures sharply defined; interstices flat, $2-3 \times$ broader than striae, covered 
with irregular rugosity; vestiture consisting of recumbent hair-like scales, and weakly raised, longer hair-like scales.

Legs moderately robust; all femora unarmed; apex of fore tibiae indistinctly enlarged, ventral margin with long semi-erect setae; tarsi slender, second segment subisodiametric.

Ventral part of thorax covered with rather sparse recumbent hairs, ventrites covered with much denser hairs; last ventrite apically broadly rounded.

Aedeagus (Fig. 2) widest basally, then only indistinctly tapering to the base of apex; the latter subtriangular, top rounded; in lateral view moderately evenly arched (Fig. 3).

\section{Female}

Unknown.

\section{Distribution}

So far only known from the locus typicus in extreme south-western Bulgaria.

\section{Etymology}

I affectionately dedicate this new species to Attila PoDLUSSÁNY (Budapest, Hungary), his late wife Judith, and his sister Erzsébet in appreciation of the great hospitality I experienced during my several stays in Budapest.

\section{Otiorhynchus (Choilisanus) brunneiformis sp. $\mathbf{n}$.}

(Fig. 4-7)

\section{Material examined}

Holotype [fore right tarsus except first segment; fore right onychium; left middle tarsus except first segment, missing]: Aydin 28.4.1984 Y.Ot/ Turkey-W. distr. Aydin [in pencil] [MERE].

\section{Diagnosis}

In the head structure the new species most closely resembles Otiorhynchus brunneus GYLLENHAL, 1834 and is probably closely related to this species. The new species (Fig. 4) differs from O. brunneus above all in the strikingly smaller, less convex pronotal tubercles, the more elongate elytra, the strikingly less convex declivity (in $O$. brunneus elytra $1.3 \times$ broader than long, declivity strongly convex, somewhat overhanging, as a result elytra "subrectangular" in profile), and the less transverse prothorax (in O. brunneus $1.3 \times$ ). 


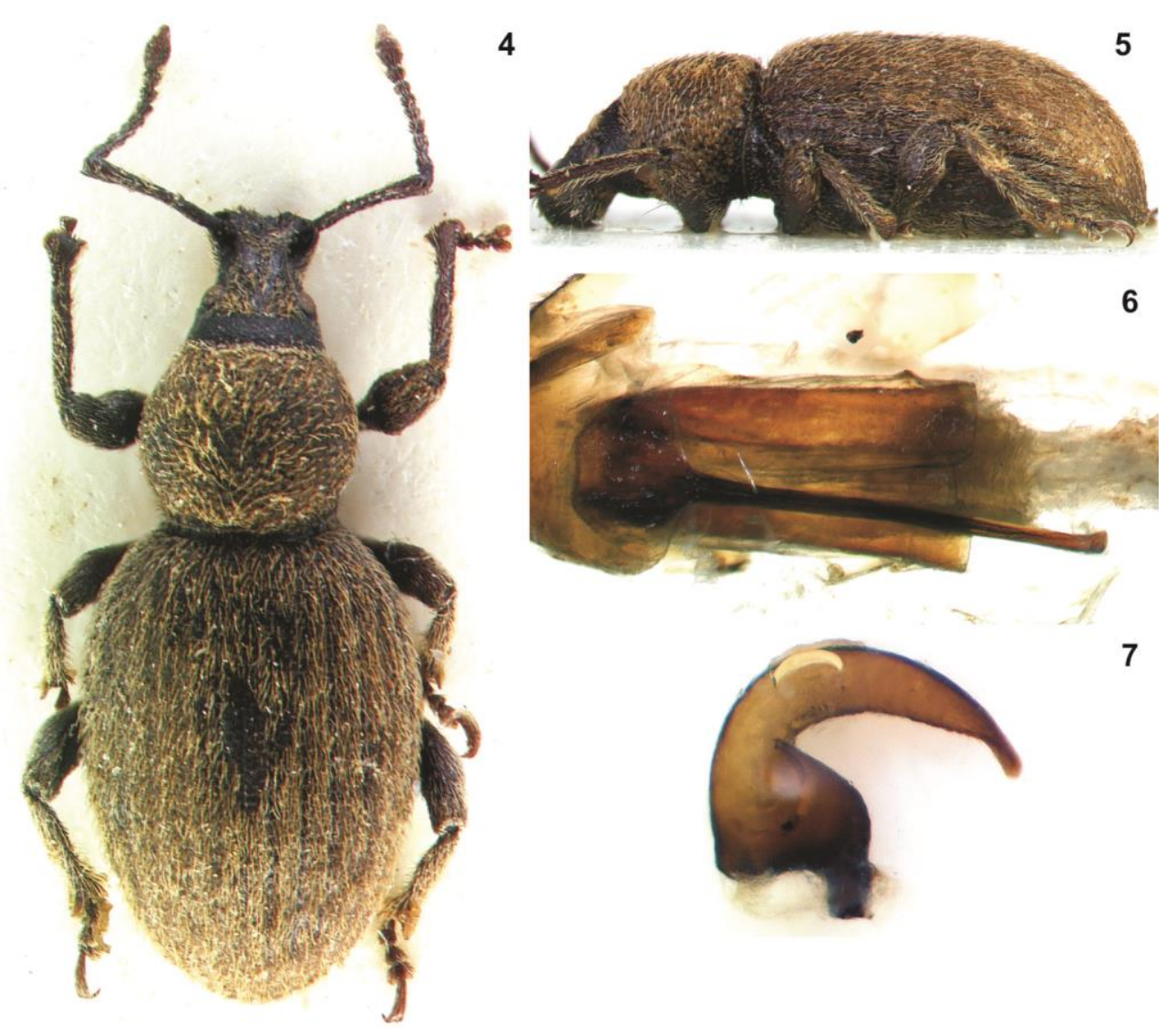

Figs. 4-7. Otiorhynchus brunneiformis sp. n.: 4 - female habitus, 5 - female profile, 6 - female terminalia, 7 - spermatheca.

\section{Description (female)}

Body length $6.6 \mathrm{~mm}$.

Head forming common cone together with basal part of rostrum; covered with very dense minute shallow punctures; frons well separated from dorsal wall of rostrum; frons fovea not recognizable; vestiture consisting of light-coloured, rather short weakly raised hair-like scales; eyes fairly weakly convex, well projecting; temples subequally long as eye diameter.

Rostrum relatively strongly transverse, $1.25 \times$ wider than long; pterygia moderately large, rather weakly projecting; epistome moderately hollowed, delimited by very thin lateral keels; dorsal wall moderately divergent backwardly; lateral margins well expressed; 
median keel narrow and shallow but well visible; vestiture consisting of short, very thin weakly perceptible hairs.

Antennae relatively slender; scape nearly straight, only apically weakly swollen; first two funicle segments subcylindrical, much longer than all other segments; third weakly elongate; 4-6 subisodiametric; $7^{\text {th }}$ rather weakly transverse; club narrowly ovate.

Prothorax $1.2 \times$ broader than long, at sides weakly evenly arched, widest in middle; disc transversally strongly convex, covered with minute dense tubercles; vestiture consisting of hair-like scales moderately dense, longer than on head, almost semi-erect.

Elytra $1.45 \times$ longer than broad; broader somewhat before middle, relatively strongly narrowed apically; longitudinally weakly evenly convex (Fig. 5), declivity strikingly less convex than basal part of elytra, as a result elytra in profile "subtrapezoidal"; striae well impressed but moderately narrow; punctures rather small, 2-3 narrower than interstices but distinctly larger than pronotal tubercles; interstices wide, covered with moderately sparse microtubercles and very dense relatively short subrecumbent bright hairs intermixed with long semi-erect dense bright setae.

Legs average; fore tibiae straight, apex moderately dilated; tarsi slender, second segment somewhat transverse; middle and hind tibiae strongly enlarged apically; each tibia with moderately large red-brown mucro.

Venter covered with moderately sparse, moderately long subrecumbent hairs.

Female $8^{\text {th }}$ sternite (Fig. 6) slightly transverse, apically hardly emarginate; spiculum ventrale somewhat more than $3 \times$ as long as sternite itself, with minute caput; ovipositor moderately sclerotized, as long as spiculum ventrale; spermatheca with rather short but strongly inflated corpus, ramus very short and wide, weakly differentiated (Fig. 7).

\section{Male}

Unknown.

\section{Distribution}

So far, known from the locus typicus (exact location unknown) in the Aegean province of Aydin (W Turkey).

\section{Etymology}

The name intentionally refers to Otiorhynchus brunneus, presumably closely related to the new species. 


\section{Otiorhynchus (Choilisanus) mogulonoides sp. n.}

(Figs. 8-11)

\section{Material examined}

Holotype female, dissected: Anatolien. Agreres [?]-pass. HeINZ. 6.8.64.[“Agreres" not found in any source]/ Otiorrhynch. det. v. BUDBERG [reverse] [NHMW]. Paratype: Anatolia mer. W. \& U. HEINZ leg./ Taurus 1500-2000 m südl. Eregli 31.7-1.8.[19]64 [BIAL].

\section{Diagnosis}

The new species (Fig. 8) is recognizable at first glance as belonging to the Otiorhynchus plagigerulus-group by the large subtriangular tooth on all the femora. Within the group it is easily identified by the small body, the elytral declivity slightly bent under, and the entirely recumbent vestiture. It differs from both O. plagigerulus BIAŁOOKI, 2016 and O. aziziyensis DAVIDIAN \& GÜLTEKIN, 2015 (the three species have fore femora with a large triangular tooth excised on the distal margin) in the shorter elytra, and the entirely recumbent vestiture of a different colour.

\section{Description (female)}

Body length 6.0-6.1 mm, ht $6.0 \mathrm{~mm}$; body black, legs and antennae in part dark brown. Body covered with recumbent elongate greyish-light brown pointed scales creating unclear maculation, integument (nearly) completely obscured.

Head clearly separated from basal part of rostrum; frons flat longitudinally, clearly convex transversally, covered with large dense punctures in part fused longitudinally, largely obscured by recumbent elongate pointed scales distinctly larger than on vertex; frons fovea weakly visible, narrowly elongate; eyes slightly elongate, rather weakly convex, well protruding from head convexity but not projecting.

Rostrum slightly wider than long; pterygia very large; epistome symmetrically triangular, normally hollowed, with well-expressed keels and minute horns; hind portion of dorsal wall of rostrum subparallelsided, with unclear lateral margins, median keel well developed; surface sculptured and scaled as frons, integument mostly obscured by vestiture.

Antennae short and robust; scape straight; apical portion somewhat swollen; first funicle segment longer than second; segments 3-7 all subequally large, moderately transverse; club narrowly fusiform, only somewhat wider than funicle.

Prothorax $1.2 \times$ broader than long, base somewhat wider than anterior margin; laterally moderately strongly arched, widest behind middle; disc covered with very dense, minute punctures; punctation nearly completely obscured by recumbent scales similar to that on frons; scales greyish light-brown. 


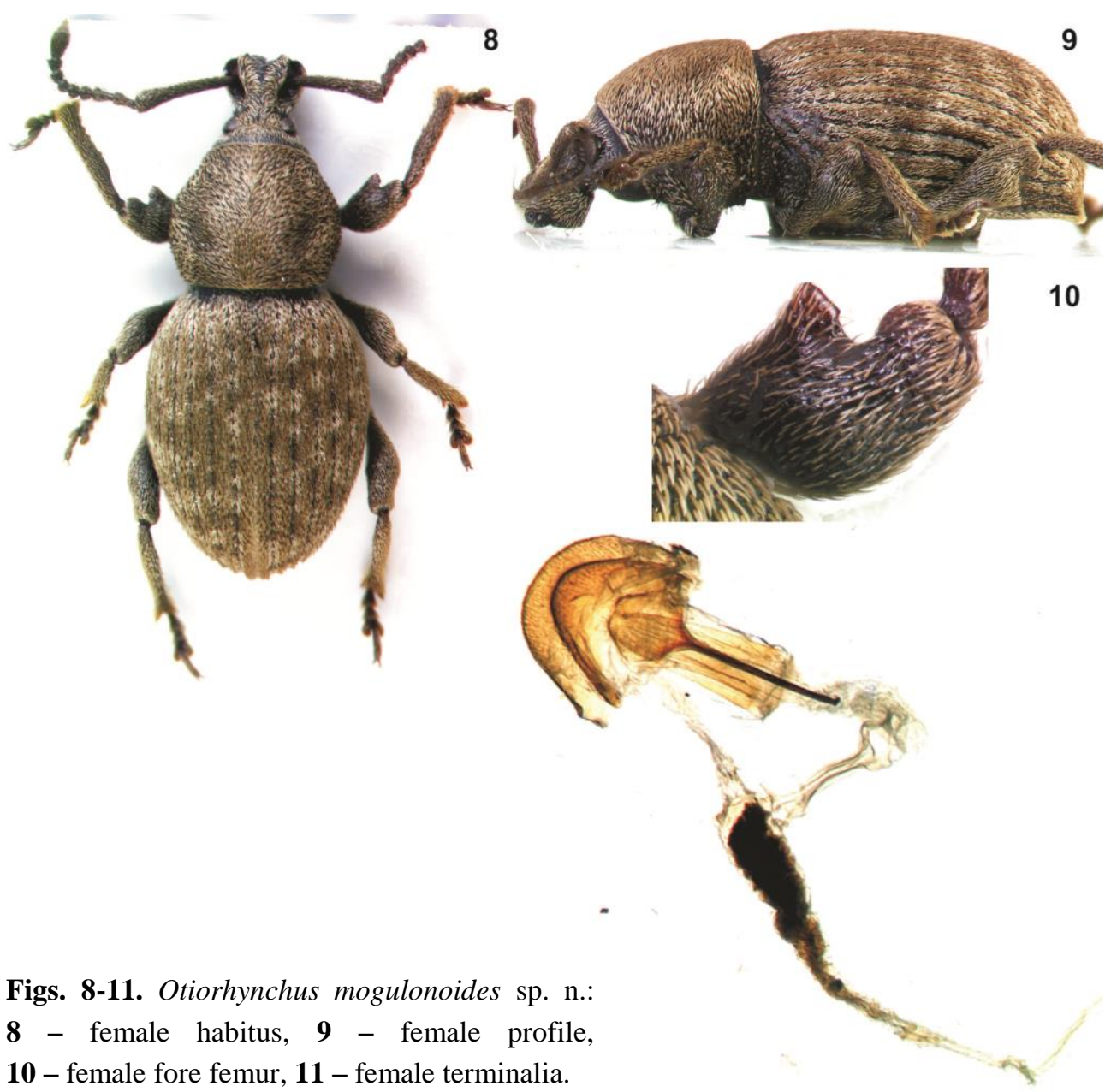

Elytra widest at basal one third; longitudinally rather weakly, evenly convex, declivity moderately strongly convex (Fig. 9); striae slightly impressed, very narrow, punctures small, well delimited; interstices 3-4 $\times$ broader than striae, flat, only somewhat convex on declivity; entire surface covered with recumbent scales similar to that on pronotum.

Legs short and robust; fore femora much larger than others; all femora with subequally large, triangular tooth (Fig. 10) with emarginate distal margin, resembling condition known in some species of the genus Mogulones Reitter, 1916 (Conoderinae: Ceutorhynchini); hind tibiae distinctly arched (apically upcurved); femora covered with recumbent moderately dense bright hair-like scales. 
Spermatheca with long thin arched cornu, corpus distinctly inflated, ramus hardly marked, gland much longer than length of spermatheca; $8^{\text {th }}$ sternite slightly transverse, distally with very shallow emargination; spiculum ventrale twice as long as sternite; ovipositor with well-developed subapical styli (Fig. 11).

\section{Male}

Unknown.

\section{Distribution}

The only known locality is the vicinity of Eregli in southern Turkey; the locality of the second specimen cannot be established because the label is illegible.

\section{Etymology}

The name (a noun in apposition) intentionally refers to the ceutorhynchine genus Mogulones: an allusion to the femoral teeth in the new species strikingly resembling several species of that genus.

\section{ACKNOWLEDGEMENTS}

I would like to express my sincere gratitude to all my colleagues who helped me during the preparation of this paper: Massimo Meregalli, University of Torino, Italy; Attila PODLUSSÁNY, Hungarian Natural History Museum, Budapest, Hungary; Harald SCHILLHAMmER, Naturhistorisches Museum Wien, Austria, for the loans of material from their collections/institutions; and to Marek WANAT, University of Wroclaw, Poland for the opportunity to take photographs and great hospitality during my visits to Wroclaw as well as for reviewing the text. Thanks are also due to the two anonymous reviewers

\section{REFERENCES}

Alonso-Zarazaga M.A., Barrios H., Borovec R., Bouchard P., Caldara R., Colonnelli E., Gültekin L., Hlaváč P., Korotyaev B., Lyal C.H.C., Machado A., Meregalli M., Pierotti H., Ren L., Sánchez-Ruiz M., Sforzi A., Silfyerberg H., Skuhrovec J., TrÝzna M., Velázquez de Castro A.J., Yunakov N.N. 2017. Cooperative Catalogue of Palaearctic Coleoptera Curculionoidea. Monografias electronicas SEA 8, Zaragoza.

BIAŁOOKI P.Z. 2015. Descriptions of new taxa in Otiorhynchus GeRMAR, 1822 (Coleoptera: Curculionidae: Entiminae: Otiorhynchini). Polish Journal of Entomology, 84 (1): 85-99. 
BIAŁOOKI P.Z:: New species of the subgenus Choloisanus from Turkey and Bulgaria 289

BIAŁOOKI P.Z. 2016. Towards a revision of the genus Otiorhynchus Germar, 1822 subgenus Choilisanus REITTER, 1912 with descriptions of new species (Coleoptera: Curculionidae: Entiminae: Otiorhynchini). Polish Journal of Entomology, 85 (1) 147-176.

DuPorte E.M. 1960. Evolution of cranial structures in adult Coleoptera. Canadian Journal of Zoology, 38 (3): 655-675.

Oberprieler R., Anderson R.S., Marvaldi A.E. 2014. Curculionoidea Latreille, 1802: Introduction, Phylogeny. [in:] R.A.B. LeSChEN, R.G. Beutel (eds.). Handbook of Zoology. Arthropoda: Insecta: Coleoptera, Beetles. Volume 3: Morphology and Systematics. Walter De Gruyter, Boston - Berlin, 285-300.

Received: 21 January 2018

Accepted: 27 August 2018 